\title{
Fresh, equilibrated and post-thaw sperm quality of Brycon orbignyanus (Valenciennes, 1850) and Prochilodus lineatus (Valenciennes, 1837) treated with either salmon GnRHa and domperidone or pituitary extract
}

\author{
Ana T.M. Viveiros, Antonio C.S. Gonçalves, Ariane F. Nascimento and Marcelo C. Leal
}

The effects of reduced doses of Ovaprim ${ }^{\mathrm{TM}}(\mathrm{GnRHa}+$ domperidone) on sperm release of Brycon orbignyanus and Prochilodus lineatus were evaluated. Furthermore, sperm quality was compared among fresh, equilibrated and postthaw samples. Males received a single and reduced dose of Ovaprim ${ }^{\mathrm{TM}}(0.125$ or $0.25 \mathrm{ml} / \mathrm{kg})$; control males received pituitary extract (cPE; $3 \mathrm{mg} / \mathrm{kg}$ ). Fresh sperm was evaluated for volume, concentration, seminal plasma osmolality and seminal plasma $\mathrm{pH}$. Then sperm was diluted in a freezing medium, equilibrated for 15-20 min and frozen in nitrogen vapor vessel (dry-shipper). Sperm motility was analyzed during $60 \mathrm{~s}$ post-activation in fresh, equilibrated and post-thaw samples. Sperm quality of males treated with Ovaprim ${ }^{\mathrm{TM}}$ (both doses) were not different from that of cPE-treated males, thus these data were pooled. In B. orbignyanus, motility was higher in fresh (99\%) than in equilibrated sperm (81\%); post-thaw motility dropped to $42 \%$. In P. lineatus, motility was similar in fresh (99\%) and equilibrated sperm (92\%); post-thaw motility was $73 \%$. Motility decreased as a function of time post-activation, and this decrease was significant after $60 \mathrm{~s}$ in fresh and equilibrated sperm, and as soon as $30 \mathrm{~s}$ in post-thaw sperm, in both species. Ovaprim ${ }^{\mathrm{TM}}$ at $1 / 4$ of the recommended dose can successfully replace cPE.

O efeito de doses reduzidas de Ovaprim ${ }^{\circledR}$ (GnRHa + domperidona) na liberação do sêmen de Brycon orbignyanus e Prochilodus lineatus foi avaliado. Além disso, a qualidade do sêmen foi comparada entre as amostras frescas, equilibradas e descongeladas. Os machos receberam dose única e reduzida de Ovaprim ${ }^{\circledR}(0,125$ ou $0,25 \mathrm{ml} / \mathrm{kg})$; os machos-controle receberam extrato de hipófise (cPE; $3 \mathrm{mg} / \mathrm{kg}$ ). O sêmen fresco foi avaliado quanto ao volume, concentração, e osmolalidade e pH do plasma seminal. Em seguida, o sêmen foi diluído num meio de congelamento, equilibrado por 15-20 min e congelado em botijão de vapor de nitrogênio (dry-shipper). A motilidade espermática foi analisada durante $60 \mathrm{~s}$ pósativação no sêmen fresco, equilibrado e descongelado. A qualidade do sêmen não diferiu entre os machos tratados com Ovaprim $^{\circledR}$ (ambas as doses) ou cPE, assim foi feito um pool desses dados. Em B. orbignyanus, a motilidade foi maior no sêmen fresco (99\%) do que no equilibrado (81\%); a motilidade do sêmen descongelado caiu para 42\%. Em P. lineatus, a motilidade foi semelhante entre o sêmen fresco (99\%) e equilibrado (92\%); a motilidade do sêmen descongelado foi $73 \%$. A motilidade caiu em função do tempo pós-ativação, e essa queda foi significante após $60 \mathrm{~s}$ no sêmen fresco e equilibrado, e tão precoce quanto $30 \mathrm{~s}$ no sêmen descongelado, em ambas as espécies. Ovaprim ${ }^{\circledR}$ a $1 / 4$ da dose recomendada pode substituir o cPE com sucesso.

Keywords: CASA, Characiformes, cryopreservation, Ovaprim ${ }^{\mathrm{TM}}$, sperm motility.

\section{Introduction}

The piracanjuba Brycon orbignyanus and the streaked prochilod Prochilodus lineatus are migratory Characiformes species native to South America. The B. orbignyanus belongs to the family Characidae, is endemic to the Paraná-Paraguay River basin (Godoy, 1975) and its population is declining due mainly to overfishing, destruction of riparian vegetation, pollution and construction of hydroelectric dams (Rosa \& Lima, 2008). Brycon orbignyanus has a great potential for aquaculture and restocking programs, for recreational fisheries, and artificial propagation; reintroduction have been emphasized for conservation, management and recovery of this species (Maria et al., 2006). Prochilodus lineatus belongs to the family Prochilodontidae and has a large geographical distribution in the Prata River basin

Universidade Federal de Lavras (UFLA), Dept ${ }^{\circ}$ de Zootecnia, caixa postal 3037, 37200-000 Lavras, MG, Brazil. (ATMV) anatmviveiros@outlook.com (corresponding author); (ASCG) antonycarl2003@yahoo.com.br; (AFN) arianefn@hotmail.com; (MCL) marcelocleal@yahoo.com.br 
and Paraíba River basin (Godoy, 1975). Because P. lineatus larvae are used as live food for endangered carnivorous species such as B. orbignyanus and Zungaro jahu (Ihering, 1898), in addition to serving as a human food source, $P$. lineatus are of great importance to the aquaculture industry (Viveiros et al., 2009). As artificial reproduction methods are well established and its ability to produce an offspring with a large number of individuals is high, the $P$. lineatus has been used as a model species for research in a number of studies addressing nutrition, health, genetic diversity and reproduction (Viveiros et al., 2010).

Like the vast majority of fish species reared in captivity, $B$. orbignyanus and $P$. lineatus exhibit some form of reproductive dysfunction. In females there is a failure to undergo final oocyte maturation, ovulation and spawning, while in males sperm production is reduced and/or of low quality. Such reproductive dysfunctions are mainly due to the fact that fish in captivity do not experience the natural conditions of the spawning grounds and as a result the pituitary fails to release the maturational gonadotropin, luteinizing hormone (LH), (Zohar \& Mylonas, 2001). Therefore, the use of hormone therapy to increase semen volume and quality is a common technique in several species, including the Characiformes.

Despite the great success of pituitary extract (PE) as spermiation inducer of several fish species, its use has been associated with various drawbacks such as the great variability in pituitary luteinizing hormone (LH) content, and the potential for disease transmission from donor fish to recipient broodstock (Zohar \& Mylonas, 2001). These concerns led the Brazilian Ministry of Agriculture (MAPA) to prohibit the use of PE in some States, including Minas Gerais. Ovaprim $^{\mathrm{TM}}$ is a commercial product that contains a combination of salmon gonadotropin releasing hormone analog (sGnRHa) and a dopamine antagonist, that has been used with success in species of Cypriniformes (Cejko et al., 2008, 2012; Jamróz et al., 2008; Seifi et al., 2011), Osmeriformes (Król et al., 2009), Siluriformes (Viveiros et al., 2002), among others, at the recommended dose of $0.5 \mathrm{~mL} / \mathrm{kg}$ BW set by the manufacturer. To the best of our knowledge, the efficiency of Ovaprim ${ }^{\mathrm{TM}}$ as spermiation inducer has been reported in only two Characiformes species. P. lineatus males treated with a primer dose of Clarias PE $(0.4 \mathrm{mg} / \mathrm{kg})$ followed by a dose of Ovaprim ${ }^{\mathrm{TM}}$ $(0.25 \mathrm{~mL} / \mathrm{kg})$ produced semen volume, sperm concentration, sperm motility rate, sperm velocities, semen $\mathrm{pH}$ and semen osmolality not significantly different from males treated with two doses of Clarias PE $(0.4+4 \mathrm{mg} / \mathrm{kg})$ (Viveiros et al., 2013). Similarly, semen volume and concentration of Colossoma macropomum (Cuvier, 1816) were not affected by $\operatorname{Ovaprim}^{\mathrm{TM}}(0.5 \mathrm{~mL} / \mathrm{kg})$ when compared to cPE $(1.5 \mathrm{mg} /$ $\mathrm{kg}$ ) treatment (Arias Acuña \& Hernández Rangel, 2009). There is a need for more research on hormone therapies to replace $\mathrm{cPE}$ in Characiformes species, such as the use of other hormones (GnRHa combined with other dopamine antagonist, and human Chorionic Gonadotropin), as well as the test of single and double doses and the least effective concentration.

The cryopreservation of fish sperm provides a tool by which reproduction is optimized during the reproductive period. Cryopreserved sperm serves as genetic bank or germplasm for endangered species such as B. orbignyanus, which may help ensure genetic diversity and reproductive success for population management strategies (Viveiros et al., 2009). Both B. orbignyanus and P. lineatus have undergone sperm cryopreservation studies, with promising results (Maria et al., 2006; Viveiros et al., 2009; among others). However, the cryopreservation process reduces post-thaw sperm motility and velocities, and increases membrane and organelles damages, as cells are exposed to toxic substances (such as cryoprotectants), osmotic shock and intracellular freezing ( $\mathrm{Li}$ et al., 2006). This loss of quality can take place even before freezing, when sperm is diluted and equilibrated in a given freezing medium. These damages can only be detected when not only postthaw samples but also equilibrated samples are evaluated. However, sperm quality of equilibrated samples is hardly determined nor reported.

Thus, in the present study, we evaluated fresh sperm quality of males treated with single and reduced doses of Ovaprim $^{\mathrm{TM}}$ and compared with that of males treated with cPE, in Prochilodus lineatus and Brycon orbignyanus. Ovaprim $^{\text {TM }}$ was tested at $1 / 2$ and $1 / 4$ of the recommended dose. Furthermore, sperm was cryopreserved and the quality was compared among fresh, equilibrated (after dilution and before freezing) and post-thaw sperm.

\section{Material and methods}

Fish handling and sperm collection. All fish were handled following the guidelines for animal experimentation in Van Zutphen et al. (2001). During the spawning season (December to February), B. orbignyanus and P. lineatus males were selected from earthen ponds of the Hydrobiology and Fish Culture Station of Furnas in the city of São José da Barra, Minas Gerais State, Brazil (2043'07' S; 46 $18^{\prime} 50^{\prime \prime}$ $\mathrm{W})$, where they were hatched and reared; during that time, fish were fed commercial diet containing $32 \%$ of crude protein. B. orbignyanus males $(n=18)$ with an average body weight (BW) of $0.9 \pm 0.1 \mathrm{~kg}$ and $P$. lineatus males $(n$ $=21$ ) with an average $\mathrm{BW}$ of $1.1 \pm 0.3 \mathrm{~kg}$ were divided into three groups. Each group received one single intramuscular dose of: cPE (Argent Chemical Laboratory, Redmond, WA, USA) at $3 \mathrm{mg} / \mathrm{kg}$ BW which is the routine method to induce spermiation in this Fish Culture Station; Ovaprim ${ }^{\mathrm{TM}}$ at 0.125 $\mathrm{mL} / \mathrm{kg} \mathrm{BW}$; or Ovaprim ${ }^{\mathrm{TM}}$ at $0.25 \mathrm{~mL} / \mathrm{kg} \mathrm{BW}$. One $\mathrm{mL}$ of Ovaprim $^{\mathrm{TM}}$ (Syndel Laboratories Ltd., Qualicum Beach, $\mathrm{BC}$, Canada) contains $20 \mu \mathrm{g}$ of salmon GnRH analogue and $10 \mathrm{mg}$ of domperidone. Water temperature was kept at approximately $27^{\circ} \mathrm{C}$. Because the hour-degree from hormone injection to spermiation is different between these two species, $B$. orbignyanus males were hand-stripped after $4 \mathrm{~h}$ 
and $P$. lineatus after $8 \mathrm{~h}$; the urogenital papilla was carefully dried, sperm was collected into glass tubes and maintained in a cooler $\left(9-11^{\circ} \mathrm{C}\right)$ containing dry ice foam (Polar Technics CRI Ltd., Brazil). Sperm collection was carried out at room temperature $\left(22-24^{\circ} \mathrm{C}\right)$, and contamination with water, feces or urine was carefully avoided.

Fresh sperm evaluation. Immediately after collection, 5 $\mu \mathrm{L}$ of each sample was placed on a glass slide and observed using a light microscope (Model L1000, Bioval, Jiangbei, China) at $400 \mathrm{x}$ magnification. Motility rate (expressed as $\%$ of motile sperm) was subjectively estimated in intervals of $5 \%$ following the addition of $500 \mu \mathrm{L}$ of an activating agent, composed of a $\mathrm{NaCl}$ solution at an osmolality of $120 \pm 10 \mathrm{mOsm} / \mathrm{kg}(60-70 \mathrm{mM} \mathrm{NaCl})$, according to our previous results (Gonçalves et al., 2013). Motility velocity score (a subjective analysis of sperm velocity) was determined using an arbitrary grading system ranging from 0 (no movement) to 5 (rapidly swimming sperm), according to Viveiros et al. (2011). Because motility analysis was carried out in the field, we could not use our Computer-Assisted Sperm Analyzer (CASA); all we could transport from the lab was the light microscope. To track the decrease of sperm motility after activation, both rate and quality score were evaluated at $0(\sim 3 \mathrm{~s}), 20,40$ and 60 s post-activation. Sperm concentration (hemacytometer; Neubauer chamber; Boeco, Hamburg, Germany) was also determined. The osmolality (Semi-Micro Osmometer K-7400, Knauer, Berlin, Germany) and pH (pHmeter DM22, Digimed, São Paulo, Brazil) of the seminal plasma was measured after the centrifugation of sperm at $2000 \mathrm{x} g$ for 30 min (MiniStar, Shanghai, China). Sperm characteristics of all samples were evaluated by the same well-trained technician and at room temperature.

Equilibrated sperm evaluation. Sperm of each male was diluted in a freezing medium containing methyl glycol (Vetec Química Fina Ltda, Duque de Caxias, RJ, Brazil) as cryoprotectant and one extender, according to our previous results. Beltsville Thawing Solution $\left(\right.$ BTS $\left.^{\mathrm{TM}}\right)$ at $342 \mathrm{mOsm} / \mathrm{kg}(\sim 5 \%)$ was used as extender for B. orbignyanus sperm (Maria et al., 2006) and glucose at $315 \mathrm{mOsm} / \mathrm{kg}(\sim 5 \%)$ for $P$. lineatus sperm (Viveiros et al., 2009). BTS ${ }^{\text {TM }}$ (Minitub ${ }^{\text {TM }}$, Tiefenbach, Landshut, Germany) contains $222.0 \mathrm{mM}$ glucose, $24.4 \mathrm{mM}$ sodium citrate, 4.4 mM EDTA, $15.4 \mathrm{mM} \mathrm{NaHCO}_{3}, 10.7 \mathrm{mM} \mathrm{KCl}$ and $5 \mathrm{~g} / \mathrm{L}$ gentamycin sulfate. The final dilution ratio was set at $10 \%$ sperm, 10\% methyl glycol and 80\% extender. After 10-15 min of equilibration time in a cooler $\left(9-11^{\circ} \mathrm{C}\right)$ containing dry ice foam, motility rate and motility velocity score were subjectively estimated at $0,20,40$ and 60 s post-activation, as described for fresh sperm analysis.

Sperm cryopreservation and post-thaw sperm evaluation. During the $15-20 \mathrm{~min}$ equilibration time, sperm was loaded into triplicate straws. The total amount of straws was 54 for B. orbignyanus (three $0.25-\mathrm{mL}$ straws x 3 hormone treatments x 6 males) and 63 for $P$. lineatus (three $0.5-\mathrm{mL}$-straws $\mathrm{x} 3$ hormone treatments $\mathrm{x} 7$ males). All straws were frozen in a nitrogen vapor vessel (Cryoporter $\mathrm{LN}_{2}$ dry vapor shipper, Cryoport Systems, Brea, CA, USA) at approximately $-170^{\circ} \mathrm{C}$, immediately transported from Furnas to the Laboratory of Semen Technology at the Federal University of Lavras (UFLA), Lavras, Minas Gerais, Brazil (approximately $250 \mathrm{~km}$ ) and then transferred to liquid nitrogen vessel (M.V.E. Millenium, XC 20 , Chart, $\mathrm{MN}, \mathrm{USA}$ ) at $-196^{\circ} \mathrm{C}$ within 20 to $24 \mathrm{~h}$ for storage.

Approximately two months later, straws were thawed in a $60^{\circ} \mathrm{C}$ water bath (Water-bath MA 127 , Marconi, Brazil) for $3 \mathrm{~s}(0.25 \mathrm{~mL}$ straws $)$ or for $8 \mathrm{~s}(0.5 \mathrm{~mL}$ straws $)$, and post-thaw sperm quality was estimated using the CASA system (Computer-Assisted Sperm Analyzer), following the methodology described in Viveiros et al. (2013). Briefly, post-thaw sperm was activated directly in a Makler ${ }^{\mathrm{TM}}$ counting chamber (Sefi-Medical Instruments ltd, Haifa, Israel) to a final dilution ratio of 1:50 (B. orbignyanus) or 1:500 (P. lineatus). The Makler ${ }^{\mathrm{TM}}$ chamber was placed under a phase-contrast microscope (Nikon Eclipse E200, Tokyo, Japan) at $100 \mathrm{x}$ magnification with a green filter and $\mathrm{pH} 1$ position. The microscope was connected to a video camera (Basler Vision Technologies ${ }^{\mathrm{TM}} \mathrm{A} 602 \mathrm{FC}$, Ahrensburg, Germany) generating 100 images/s at 10, 30, 50 and $70 \mathrm{~s}$ post-activation (1 $\mathrm{s}$ of video at each evaluation time). We could not analyze motility at $0 \mathrm{~s}$ post-activation, as we did for fresh and equilibrated sperm, because it takes approximately $10 \mathrm{~s}$ to cover the Makler ${ }^{\mathrm{TM}}$ chamber, focus and find a good field for motility analysis. Each image was analyzed using the adjusted settings for fish by Sperm Class Analyzer ${ }^{\mathrm{TM}}$ software (SCA ${ }^{\mathrm{TM}} 2010$, Microptics, S.L. Version 5.1, Barcelona, Spain). Although the $\mathrm{SCA}^{\mathrm{TM}}$ simultaneously assesses more than 15 sperm motility endpoints, for brevity, only motility rate, curvilinear velocity (VCL), straight-line velocity (VSL) and average path velocity (VAP) were considered for analysis. To determine these parameters, each individual sperm (a mean of $731 \mathrm{~B}$. orbignyanus sperm per field and $383 P$. lineatus sperm per field) were followed throughout the images and sperm trajectory was calculated.

Statistical analysis. The values are expressed as mean \pm standard deviation (SD). Statistical analyses were conducted using the $\mathrm{R}$ Development Core Team Computational Program (2010). Data were evaluated for normal distribution using the Shapiro-Wilk test. Data on subjective motility, quality motility score, seminal plasma osmolality and VCL did not fit the normal distribution and thus arcsin transformation was performed. Statistical significance was tested using analysis of variance (ANOVA) followed by Scott-Knott test when applicable. The level of significance for all statistical tests was set to $5 \%(\mathrm{P}<0.05)$. 


\section{Results}

Fresh sperm motility. All males responded to the Ovaprim $^{\mathrm{TM}}$ and $\mathrm{cPE}$ treatments and were thus stripped of sperm. Fresh sperm quality parameters of ovaprim-treated males (both doses) were not different $(\mathrm{P}>0.05)$ from cPEtreated males (Table 1). All together, the 18 B. orbignyanus males (pooled data) possessed a mean semen volume of 8.8 $\mathrm{mL}$, concentration of $12.4 \times 10^{9}$ spermatozoa $/ \mathrm{mL}$, motility rate of $99 \%$, motility velocity score of 4.9 , seminal plasma osmolality of $300 \mathrm{mOsm} / \mathrm{kg}$ and $\mathrm{pH}$ of 7.7. The 21 P. lineatus males (pooled data) possessed a mean semen volume of 3.1 $\mathrm{mL}$, concentration of $27.3 \times 10^{9}$ spermatozoa/mL, motility rate of $99 \%$, motility velocity score of 4.9 , seminal plasma osmolality of $271 \mathrm{mOsm} / \mathrm{kg}$ and $\mathrm{pH}$ of 7.8 .

In order to track the decrease of fresh sperm motility after activation, both rate and velocity score were evaluated during $60 \mathrm{~s}$. As these results were similar between ovaprim- and cPE-treated males, the data were pooled per fish species (Table 2). Motility decreased slowly as a function of time and was significantly lower when evaluated after $60 \mathrm{~s}$ compared to that at $0 \mathrm{~s}$. Motility of $B$. orbignyanus fresh sperm decreased from a rate of 99 to $88 \%$ and from a velocity score of 4.9 to 3.7 , and of $P$. lineatus sperm decreased from a rate of 99 to $84 \%$ and from a quality score of 4.9 to 3.6 after $60 \mathrm{~s}$ of analysis.
Equilibrated sperm motility. Motility evaluated after a 10-15 min of sperm contact with the freezing medium (equilibrated samples) and for a period of $60 \mathrm{~s}$ postactivation was also not affected by Ovaprim ${ }^{\mathrm{TM}}$ treatment. Thus, to facilitate the description of these results the data were pooled per fish species (Table 2). Motility decreased slowly as a function of time and was significantly lower when evaluated after $60 \mathrm{~s}$ compared to that at $0 \mathrm{~s}$. Motility of $B$. orbignyanus equilibrated sperm decreased from a rate of 81 to $66 \%$ and from a quality score of 3.9 to 2.6 , and of $P$. lineatus sperm decreased from a rate of 92 to $73 \%$ and from a quality score of 4.3 to 2.9 after $60 \mathrm{~s}$ of analysis.

Fresh $\mathbf{x}$ equilibrated sperm motility. Because fresh ad equilibrated samples were both analyzed for subjective motility in the field, we could carry out some statistical analysis among these data (Table 2 ). In B. orbignyanus, motility rate and velocity score were always higher $(\mathrm{P}<0.05)$ in fresh sperm (99-88\%; score 4.9-3.7) compared to sperm equilibrated in the freezing medium $(81-66 \%$; score 3.9-2.6), at all observation times. In $P$. lineatus, motility rate was similar between fresh (99-84\%) and equilibrated sperm $(92-73 \%)$, while motility velocity score was always higher $(\mathrm{P}<0.05)$ in fresh $(4.9-3.6)$ compared to equilibrated sperm (4.3-2.9), at all observation times.

Table 1. Male body weight and fresh sperm quality (mean \pm SD) of Brycon orbignyanus and Prochilodus lineatus males after treatment with a single dose of carp pituitary extract (cPE) or Ovaprim ${ }^{\mathrm{TM}}$.

\begin{tabular}{|c|c|c|c|c|}
\hline \multirow[b]{2}{*}{ Features } & \multicolumn{3}{|c|}{ Hormonal treatment $(/ \mathrm{kg} \mathrm{BW})$} & \multirow{2}{*}{$\begin{array}{c}\text { Overall } \\
\text { mean }\end{array}$} \\
\hline & $\begin{array}{c}\mathrm{cPE} \\
(3 \mathrm{mg})\end{array}$ & $\begin{array}{c}\text { Ovaprim }^{\mathrm{TM}} \\
(0.125 \mathrm{~mL})\end{array}$ & $\begin{array}{l}\text { Ovaprim }^{\mathrm{TM}} \\
(0.25 \mathrm{~mL})\end{array}$ & \\
\hline Spermiated/treated males & $6 / 6$ & $6 / 6$ & $6 / 6$ & $18 / 18$ \\
\hline Body weight (kg) & $0.9 \pm 0.1$ & $0.8 \pm 0.1$ & $0.9 \pm 0.1$ & $0.9 \pm 0.1$ \\
\hline Concentration (sperm $\times 10^{9} / \mathrm{mL}$ ) & $11.9 \pm 0.4$ & $12.1 \pm 1.8$ & $13.4 \pm 2.1$ & $12.4 \pm 1.7$ \\
\hline Subjective motility rate (\%) & $98 \pm 4$ & $98 \pm 4$ & $100 \pm 0$ & $99 \pm 3$ \\
\hline Motility velocity score ${ }^{1}(0-5)$ & $5.0 \pm 0.0$ & $4.8 \pm 0.4$ & $5.0 \pm 0.0$ & $4.9 \pm 0.2$ \\
\hline Seminal plasma mOsm $/ \mathrm{kg}$ & $303 \pm 15$ & $302 \pm 13$ & $294 \pm 10$ & $300 \pm 13$ \\
\hline Seminal plasma $\mathrm{pH}$ & $7.8 \pm 0.1$ & $7.6 \pm 0.3$ & $7.8 \pm 0.2$ & $7.7 \pm 0.2$ \\
\hline Semen volume $(\mathrm{mL})$ & $2.9 \pm 1.4$ & $3.0 \pm 1.5$ & $3.4 \pm 1.4$ & $3.1 \pm 1.4$ \\
\hline Concentration (sperm $\times 10^{9} / \mathrm{mL}$ ) & $28.5 \pm 2.0$ & $25.3 \pm 3.4$ & $28.1 \pm 3.0$ & $27.3 \pm 3.1$ \\
\hline Subjective motility rate (\%) & $100 \pm 0$ & $99 \pm 4$ & $97 \pm 3$ & $99 \pm 3$ \\
\hline Motility velocity score ${ }^{1}(0-5)$ & $5.0 \pm 0.0$ & $4.9 \pm 0.4$ & $4.7 \pm 0.5$ & $4.9 \pm 0.4$ \\
\hline Seminal plasma $\mathrm{mOsm} / \mathrm{kg}$ & $258 \pm 28$ & $274 \pm 8$ & $281 \pm 8$ & $271 \pm 20$ \\
\hline Seminal plasma $\mathrm{pH}$ & $7.6 \pm 0.2$ & $7.8 \pm 0.2$ & $7.9 \pm 0.2$ & $7.8 \pm 0.3$ \\
\hline
\end{tabular}

${ }^{1}$ A motility velocity score was assigned using an arbitrary grading system from 0 (no movement) to 5 (rapidly swimming sperm).

There was no effect $(\mathrm{P}>0.05)$ of hormonal treatment on fresh sperm quality. 
Table 2. Motility rate and motility velocity score (mean \pm SD) of fresh and equilibrated sperm of Brycon orbignyanus $(n=$ 18 males) and Prochilodus lineatus ( $n=21$ males) evaluated after 0, 20, 40 and 60s of activation.

\begin{tabular}{|c|c|c|c|c|}
\hline \multirow{2}{*}{$\begin{array}{l}\text { S post-activation } \\
\text { B. orbignyanus }\end{array}$} & \multicolumn{2}{|c|}{ Motility rate (\%) } & \multicolumn{2}{|c|}{ Velocity score $(0-5)^{1}$} \\
\hline & Fresh & Equilibrated $^{2}$ & Fresh & Equilibrated $^{2}$ \\
\hline 0 & $99 \pm 3^{\mathrm{a}}$ & $81 \pm 10^{b}$ & $4.9 \pm 0.2^{\mathrm{a}}$ & $3.9 \pm 0.3^{b}$ \\
\hline 20 & $96 \pm 6^{\mathrm{a}}$ & $77 \pm 11^{\mathrm{b}}$ & $4.7 \pm 0.5^{\mathrm{a}}$ & $3.6 \pm 0.5^{\mathrm{b}}$ \\
\hline 40 & $94 \pm 7^{\mathrm{a}}$ & $71 \pm 11^{b}$ & $4.1 \pm 0.6^{\mathrm{a}}$ & $2.9 \pm 0.4^{\mathrm{b}}$ \\
\hline 60 & $88 \pm 9^{a^{*}}$ & $66 \pm 12^{b^{*}}$ & $3.7 \pm 0.5^{\mathrm{a}^{*}}$ & $2.6 \pm 0.5^{\mathrm{b} *}$ \\
\hline P. lineatus & Fresh & Equilibrated $^{2}$ & Fresh & Equilibrated $^{2}$ \\
\hline 0 & $99 \pm 3^{\mathrm{a}}$ & $92 \pm 6^{\mathrm{a}}$ & $4.9 \pm 0.4^{\mathrm{a}}$ & $4.3 \pm 0.5^{b}$ \\
\hline 20 & $96 \pm 7^{\mathrm{a}}$ & $89 \pm 9^{a}$ & $4.6 \pm 0.5^{\mathrm{a}}$ & $3.7 \pm 0.6^{b}$ \\
\hline 40 & $91 \pm 9^{\mathrm{a}}$ & $81 \pm 11^{\mathrm{a}}$ & $4.0 \pm 0.6^{\mathrm{a}}$ & $3.3 \pm 0.6^{\mathrm{b}}$ \\
\hline 60 & $84 \pm 10^{\mathrm{a}^{*}}$ & $73 \pm 15^{\mathrm{a}^{*}}$ & $3.6 \pm 0.6^{\mathrm{a} *}$ & $2.9 \pm 0.8^{\mathrm{b} *}$ \\
\hline
\end{tabular}

${ }^{1}$ Motility velocity score was assigned using an arbitrary grading system from 0 (no movement) to 5 (rapidly swimming sperm).

${ }^{2}$ Sperm was diluted in a freezing medium containing methyl glycol and an extender (BTS ${ }^{\mathrm{TM}}$ for $B$. orbignyanus and glucose for $P$. lineatus) and evaluated after a 10-15 min equilibration time.

$\mathrm{a}, \mathrm{b}$ Means within the same row followed by different lowercase, differ ( $\mathrm{F}$ test, $\mathrm{P}<0.05)$.

"Means within the same column were lower when evaluated at 60s than those evaluated at 0s post-activation (Scott-Knott, $\mathrm{P}<0.05)$.

Post-thaw sperm motility. Post-thaw sperm motility and velocities were not different $(\mathrm{P}>0.05)$ between ovaprimand cPE-treated males of both fish species. Thus, to facilitate the description of these results the data were pooled per fish species.

Motility and velocities decreased fast as a function of time after activation, and were always higher $(\mathrm{P}<0.05)$ when evaluated at $10 \mathrm{~s}$ post-activation compared to all the other observation times. Motility rate decreased from 42 to $25 \%$ in

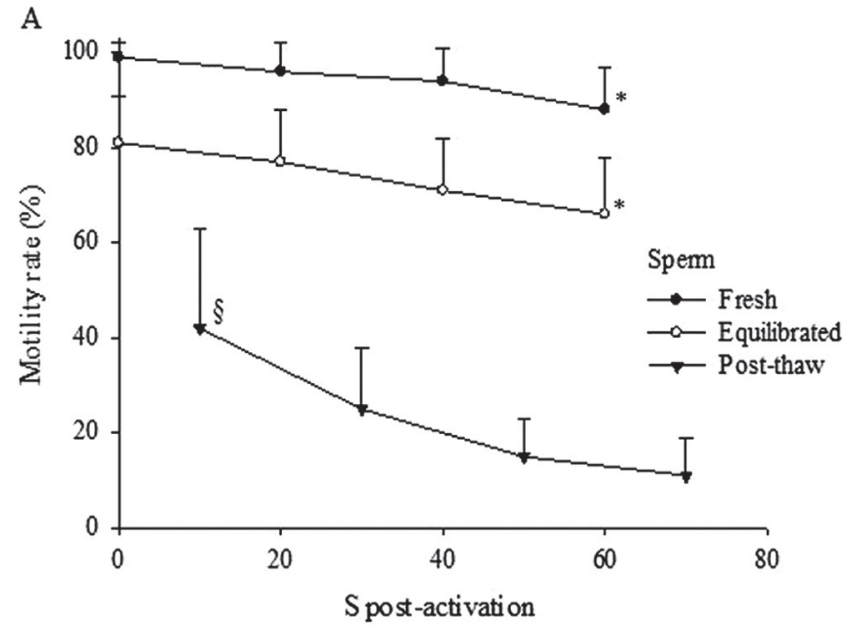

B. orbignyanus and from 73 to $54 \%$ in P. lineatus after only $20 \mathrm{~s}$ of analysis (at 10 and $30 \mathrm{~s}$ post-activation). At $70 \mathrm{~s}$ postactivation, motility rate was only $11 \%$ in $B$. orbignyanus (Figure 1A) and $12 \%$ in P. lineatus (Figure 1B). Similarly, during the first $20 \mathrm{~s}$ of analysis, VCL decreased from 160 to $101 \mu \mathrm{m} / \mathrm{s}$, VSL from 103 to $54 \mu \mathrm{m} / \mathrm{s}$ and VAP from 133 to $77 \mu \mathrm{m} / \mathrm{s}$ in B. orbignyanus (Figure 2A), while in P. lineatus VCL decreased from 277 to $126 \mu \mathrm{m} / \mathrm{s}$, VSL from 171 to 80 $\mu \mathrm{m} / \mathrm{s}$ and VAP from 254 to $100 \mu \mathrm{m} / \mathrm{s}$ (Figure $2 \mathrm{~B}$ ).

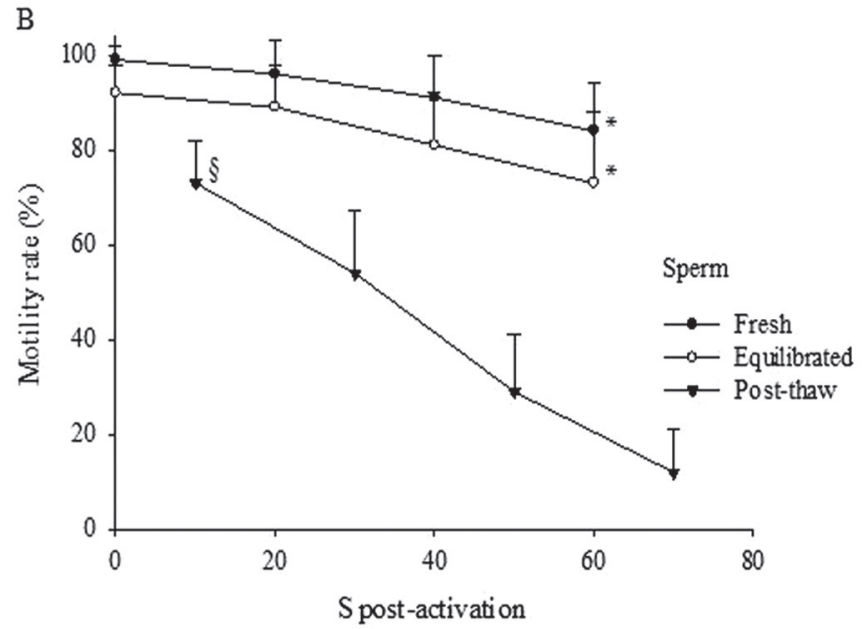

Fig. 1. Motility rate of fresh, equilibrated and post-thaw sperm of Brycon orbignyanus (A; $n=18$ males) and Prochilodus lineatus (B; $n=21$ males). Motility rate was evaluated after 0, 20, 40 and 60s (fresh and equilibrated sperm) or after $10,30,50$ and $70 \mathrm{~s}$ of activation (post-thaw sperm). ${ }^{*}$ Motility evaluated at $60 \mathrm{~s}$ was lower than that at $0 \mathrm{~s}$ post-activation (Scott-Knott, $\mathrm{P}<0.05) .{ }^{\S}$ Motility evaluated at $10 \mathrm{~s}$ post-activation was the highest (Scott-Knott, $\mathrm{P}<0.05$ ). 

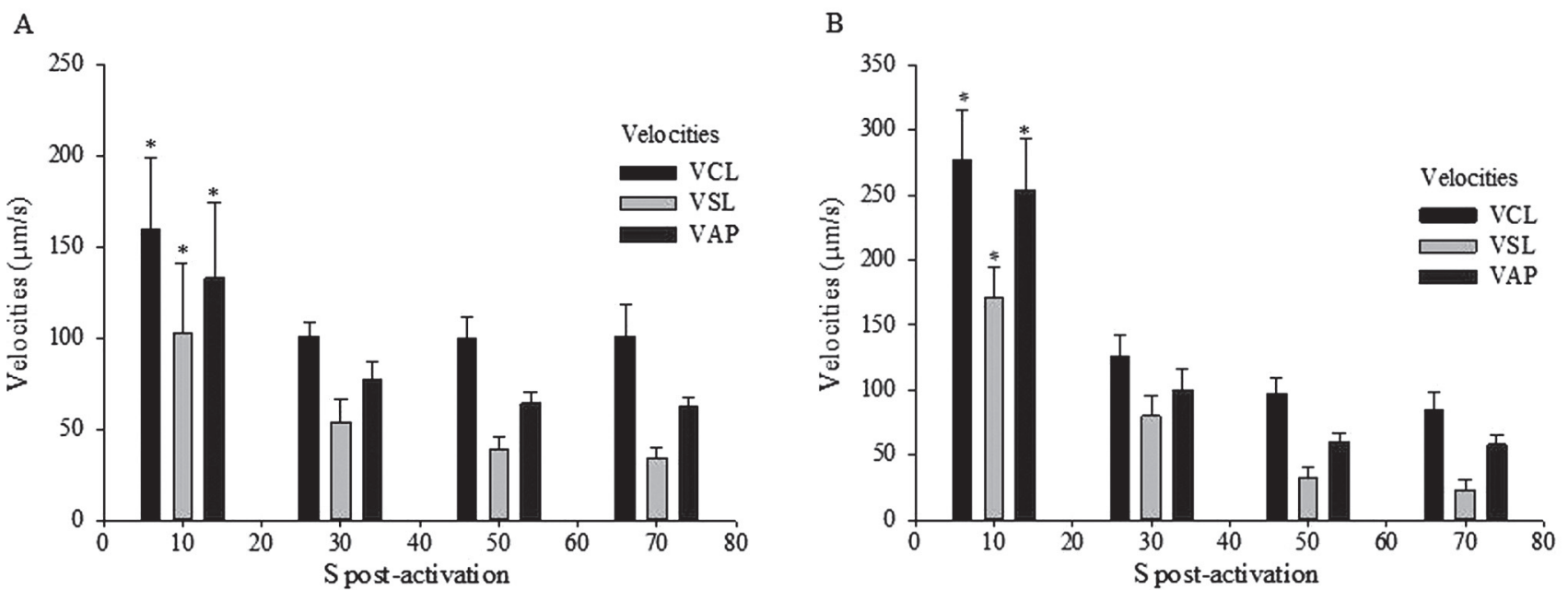

Fig. 2. Post-thaw sperm velocities (curvilinear $=$ VCL; straight-line $=$ VSL; average path $=$ VAP) of Brycon orbignyanus $(A$; $n=18$ males) and Prochilodus lineatus (B; $n=21$ males) evaluated after 10, 30, 50 and 70s after activation. ${ }^{*}$ Mean at 10s was the highest (Scott-Knott, $\mathrm{P}<0.05)$.

\section{Discussion}

The present study demonstrates for the first time the efficiency of Ovaprim ${ }^{\mathrm{TM}}$ therapy to facilitate semen collection of $B$. orbignyanus. Furthermore, we demonstrated that single and reduced doses of Ovaprim ${ }^{\mathrm{TM}}$ are as effective as cPE therapy in terms of sperm quality, even after cryopreservation, in both $B$. orbignyanus and $P$. lineatus.

Ovaprim $^{\text {TM }}$ stimulates the release of endogenous pituitary gonadotropins, while the exogenous gonadotropins present in $\mathrm{cPE}$ stimulate the gonads directly. Both therapies facilitated semen release and collection in all males, of both fish species. The values observed for sperm quality were all within the range previously reported for both fish species (Maria et al., 2006; Gonçalves et al., 2013; Nascimento et al., 2012; among others). The recommended dose of Ovaprim $^{\mathrm{TM}}$ is set at $0.5 \mathrm{~mL} / \mathrm{kg}$, yet both B. orbignyanus and $P$. lineatus males responded to lower doses, such as $1 / 2$ and $1 / 4$ of the recommended dose, without any loss of sperm quality when compared to the routine method used in the Fish Culture, the cPE. This is a great economy as one $10-\mathrm{mL}$ bottle of Ovaprim ${ }^{\text {TM }}$ contains hormones to induce spermiation of $80 \mathrm{~kg}$ of fish (at least in these two species) when administered at $0.125 \mathrm{~mL} / \mathrm{kg}$, rather than only $20 \mathrm{~kg}$ of fish using the recommended dose.

Because the evaluation of fresh and equilibrated sperm was carried out in the field, only subjective motility analysis was performed. Post-thaw motility, on the other hand, was evaluated in the lab, thus using the CASA system. Yet, we can pull out some information concerning motility rate among fresh, equilibrated and post-thaw sperm. In B. orbignyanus, motility rate significantly decreased from fresh $(99 \%)$ to equilibrated sperm (81\%), and then dropped after thawing (42\%). Similarly, motility velocity score (the subjective analysis of sperm velocity) decreased after sperm was equilibrated in the freezing medium compared to fresh samples. The freezing media utilized in this study has been tested after 30 min of equilibration (Nascimento et al., 2012) and after freezing and thawing (Maria et al., 2006) with better results compared to other media. Yet the medium composed of BTS ${ }^{\mathrm{TM}}$ and methyl glycol seems inadequate for $B$. orbignyanus sperm as motility significant decreased after only 10-15 min of contact, when compared to fresh sperm. Thus, we suggest that other freezing media should be tested during the cryopreservation of $B$. orbignyanus sperm.

On the other hand, in P. lineatus, motility rate was similar between fresh (99\%) and equilibrated sperm (92\%) and decreased only after thawing (73\%), but not to values as low as those observed for B. orbignyanus sperm. Motility velocity score, however, was lower in equilibrated samples compared to fresh ones. The freezing media utilized in this study has been tested after $30 \mathrm{~min}$ of equilibration (Nascimento et al., 2012) and after freezing and thawing (Viveiros et al., 2009, 2010) with better results compared to other media. In our laboratory, we consider high postthaw sperm quality when motility rate is above $60 \%$ and VCL is above $140 \mu \mathrm{m} / \mathrm{s}$. Thus, the freezing medium composed of glucose and methyl glycol was suitable for the cryopreservation of $P$. lineatus sperm.

In the present study, motility decreased as a function of time after activation, and this decrease was significant after $60 \mathrm{~s}$ in fresh samples. It is interesting to observe that, although significant, this decrease was not that intense as more than $80 \%$ of the sperm were still moving after $60 \mathrm{~s}$, and with a velocity score as high as 3.6-3.7. In most of the fish species, fresh sperm motility lasts from $30 \mathrm{~s}$ to few min and initial velocity is high (up to $300 \mu \mathrm{m} / \mathrm{s}$ ) (Cosson 2008). The duration of fresh sperm motility of $P$. lineatus can last up to $2 \mathrm{~min}$, as previously reported (Orfão et al., 2010). However, the freezing and thawing processes exert a strong and negative effect on the duration of sperm 
motility of both fish species. In frozen samples, motility (both rate and velocities) significantly decreased as soon as after $30 \mathrm{~s}$ post-activation. Despite the fast decrease of motility post-activation, this fact may not interfere with the fertilization ability of frozen sperm. It has been reported that Bryconinae sperm needs only few seconds (perhaps < $20 \mathrm{~s}$ ) of motility to fertilize an oocyte as several sperm were observed on the opening of the micropyle and more than one inside the micropylar canal $20 \mathrm{~s}$ after water was added (Isaú et al., 2013). However, in order to be on the safe side, we recommend the use of a higher spermatozoa:oocyte ratio when using frozen sperm for fertilization, compared to fresh sperm. In our previous study, $P$. lineatus sperm was frozen using the same freezing medium and methods as described here; after thawing, a ratio of $5 \times 10^{5}$ thawed spermatozoa per oocyte was used and a successful mean fertilization rate of $74 \%$ was achieved (Viveiros et al., 2009).

These results indicate that Ovaprim $^{\text {TM }}$ at a lower dose of $0.125 \mathrm{~mL} / \mathrm{kg}$ is a suitable therapy to facilitate the release and collection of high quality sperm in both $P$. lineatus and $B$. orbignyanus. Sperm obtained from ovaprimtreated males can be cryopreserved without any loss of quality, compared to sperm collected after cPE therapy. The methodology described above to cryopreserve $P$. lineatus sperm is efficient and maintain good sperm quality; however, other freezing media should be tested in B. orbignyanus sperm as motility decreased after dilution, even before freezing. Fertilization of oocytes using frozen sperm should be carried out with greater attention as, after activation, both sperm motility and velocities significantly decreased rapidly.

\section{Acknowledgments}

This study received funding from the Brazilian fostering agencies CNPq (PQ 302434/2011-9; 554950/2009-0; 142816/2009-4; 471393/2011-8), ANEEL P\&D Furnas (017965) and FAPEMIG (PPM 00038-13; BPD 00167-12). This research is part of A.C.S. Gonçalves' Ph.D. project. The authors thank the undergraduate students L.F.R. Pereira and M.A.G. Lemes (UFLA), and the biologists D.M. Ribeiro and M.B. Goulart (Furnas) for assistance during the experiments, and A.C. Costa (UFLA) for statistical support.

\section{References}

Arias Acuña, J. J. \& J. L. Hernández Rangel. 2009. Efectos del extracto hipofisiario de carpa común y el análogo de la GnRH sobre la maduración final del oocito y el desove de la cachama negra (Colossoma macropomum). Revista Científica FCV-Luz, 19:486-494.

Cejko, B. I., D. Kucharczyk, K. Targońska, D. Kubiak, B. Sarosiek \& J. Glogowski. 2008. Quality parameters and selected biochemical markers of asp, Aspiusaspius (L.), semen obtained after hormonal stimulation with Ovaprim or Ovopel. Archives of Polish Fisheries, 16:179-188.
Cejko, B. I., K. Targońska, R. K. Kowalski, D. Żarski, B. Sarosiek, D. Kucharczyk \& J. Glogowsk. 2012. The effectiveness of hormonal preparations (Ovopel, Ovaprim, LHRHa, hCG and CPE) in stimulating spermiation in dace Leuciscus leuciscus (L.). Journal of Applied Ichthyology, 28:873-877.

Cosson, J. J. 2008. Methods to analyse the movements of fish spermatozoa and their flagella. Pp.63-102. In: Alavi, S. M. H., J. J. Cosson, K. Coward \& G. Rafiee (Eds.). Fish spermatology. UK, Alpha Science Intl. Ltd.

Godoy, M. P. 1975. Brazilian fishes. Pp. 309. Piracicaba, Franciscana.

Gonçalves, A. C. S., A. F. Nascimento, A. C. Costa, M. C. Leal \& A. T. M. Viveiros. 2013. Initiation and suppression of sperm motility is osmolality-dependent in two South American fish species: streaked prochilod Prochilodus lineatus and piracanjuba Brycon orbignyanus. Animal Reproduction, 10:62-70.

Isaú, Z. A., E. Rizzo, T. B. Amaral, N. M. N. Mourad \& A. T. M. Viveiros. 2013. Structural analysis of oocytes, post-fertilization events and embryonic development of the Brazilian endangered teleost Brycon insignis (Characiformes). Zygote, 21:85-94.

Jamróz, M., D. Kucharczyk, A. Hakuc-Bazowska, S. Krejszeff, R. Kujawa, K. Kupren, M. Kwiatkowski, K. Targońska, D. Żarski, B. I. Cejko \& J. Glogowski. 2008. Comparing the effectiveness of Ovopel, Ovaprim, and LH-RH analogue used in the controlled reproduction of ide, Leuciscus idus (L.). Archives of Polish Fisheries, 16:363-370.

Król, J., R. K. Kowalski, A. Hliwa, G. J. Dietrich, R. Stabiński \& A. Ciereszko. 2009. The effects of commercial preparations containing two different GnRH analogues and dopamine antagonists on spermiation and sperm characteristics in the European smelt Osmerus eperlanus (L.). Aquaculture, 286: 328-331.

Li, J., Q. Liu \& S. Zhang. 2006. Evaluation of the damage in fish spermatozoa cryopreservation. Chinese Journal of Oceanology and Limnology, 24: 370-377.

Maria, A. N., A. T. M. Viveiros, R. T. F. Freitas \& A. V. Oliveira. 2006. Extenders and cryoprotectants for cooling and freezing of piracanjuba (Brycon orbignyanus) semen, an endangered Brazilian teleost fish. Aquaculture, 260: 298306.

Nascimento, A. F., A. C. S. Gonçalves, R. V. Reis Neto, M. C. Leal \& A. T. M. Viveiros. 2012. Extender composition, osmolality, cryoprotectant and equilibration time effects on fresh sperm motility of two Characiformes fish: piracanjuba (Brycon orbignyanus) and streaked prochilod (Prochilodus lineatus). Animal Reproduction, 9:103-110.

Orfão, L. H., A. N. Maria, A. F. Nascimento, Z. A. Isau \& A. T. M. Viveiros. 2010. Sperm fertility of the subtropical freshwater streaked prochilod Prochilodus lineatus (Characiformes) improved after dilution and cold storage. Aquaculture Research, 41:679-687.

R Development Core Team. 2010. A Language and Environment for Statistical Computing. Version 2.12.0. R Foundation for Statistical Computing.

Rosa, R. S. \& F. T. Lima. 2008. Os peixes ameaçados de extinção. Pp. 9-285. In: Machado, A. B. M., G. M. Drummond \& A. P. Paglia (Eds.). Livro vermelho da fauna brasileira ameaçada de extinção. Brasília, DF. Ministério do Meio Ambiente/ Fundação Biodiversitas. 
Seifi, T., M. R. Imanpoor \& A. Golpour. 2011. The effect of different hormonal treatments on semen quality parameters in cultured and wild carp. Turkish Journal of Fisheries and Aquatic Sciences. 11: 595-602.

Van Zutphen, L. F. M., V. Baumans \& A. C. Beynens. 2001. Principles of laboratory animal science. Revised edition. Amsterdam, Elsevier. 428 p.

Viveiros, A. T. M., A. C. S. Gonçalves, I. M. Di Chiacchio, A. F. Nascimento, E. Romagosa \& M. C. Leal. 2013. Gamete quality of streaked prochilod Prochilodus lineatus (Characiformes) after GnRHa and dopamine antagonist treatment. Zygote. Available from: CJO2013. DOI: 10.1017/ S0967199413000440.

Viveiros, A. T. M., L. H. Orfão, A. N. Maria \& I. B. Allaman. 2009. A simple, inexpensive and successful freezing method for curimba Prochilodus lineatus (Characiformes) semen. Animal Reproduction Science, 112:293-300.

Viveiros, A. T. M., A. F. Nascimento, L. H. Orfão \& Z. A. Isaú. 2010. Motility and fertility of the subtropical freshwater fish streaked prochilod (Prochilodus lineatus) sperm cryopreserved in powdered coconut water. Theriogenology, $74: 551-556$
Viveiros, A. T. M., T. B. Amaral, L. H. Orfão, Z. A. Isaú, D Caneppele \& M. C. Leal. 2011. Sperm cryopreservation of tiete tetra Brycon insignis (Characiformes): effects of cryoprotectants, extenders, thawing temperatures and activating agents on motility features. Aquaculture Research, 42:858-865.

Zohar, Y. \& C. C. Mylonas. 2001. Endocrine manipulations of spawning in cultured fish: from hormones to genes. Aquaculture, 197:99-136.

Submitted August 01, 2014 Accepted September 20, 2014 by Bernardo Baldisserotto Published March 31, 2015 